\title{
Activity-Dependent Change in AMPA Receptor Properties in Cerebellar Stellate Cells
}

\author{
Siqiong June Liu and Stuart G. Cull-Candy \\ Department of Pharmacology, University College London, London WC1E 6BT, United Kingdom
}

\begin{abstract}
High-frequency synaptic stimulation is thought to cause a rapid and lasting change in the expression of GluR2 subunitcontaining AMPA receptors (AMPARs) at synapses in cerebellar stellate cells. We examined whether spontaneous synaptic activity affects the expression of GluR2-containing synaptic AMPARs and whether the change in AMPAR subtypes alters their $\mathrm{Ca}^{2+}$ permeability and kinetic properties. We used intracellular spermine, which blocks GluR2-lacking receptors at depolarized potentials, to distinguish the presence of GluR2. In most cells, the spontaneous EPSC frequency was low, and evoked EPSCs displayed inwardly rectifying $I-V$ relationships, indicative of the presence of GluR2-lacking AMPARs. However, in cells that displayed a higher rate of spontaneous synaptic activity, EPSCs gave linear $I-V$ plots, suggesting the presence of GluR2-containingAMPARs. This is consistent with the idea that spontaneous synaptic activity increased the expression of GluR2-containing AMPARs at synapses. The $\mathrm{Ca}^{2+}$
\end{abstract}

permeability of AMPARs that gave inwardly rectifying currents in outside-out patches from TTX-treated cells was six times higher than in control cells that gave linear or outwardly rectifying $I-V$ plots. However, increased spontaneous synaptic activity did not significantly alter the EPSC decay time. Furthermore, the decay time course ofEPSCs mediated by GluR2-containing receptors was not different from that mediated by a mixed population of receptors at the same synapse. Our results suggest that the level of spontaneous synaptic activity can determine the subunit composition of postsynaptic receptors at this synapse. The activity-induced expression of GluR2containing receptors significantly reduced the $\mathrm{Ca}^{2+}$ permeability of AMPARs in stellate cells but did not slow the decay time course of synaptic currents.

Key words: AMPA; stellate cell; cerebellum; AMPA channels; AMPA receptor subtypes; glutamate receptors; subunits; calcium permeability
The majority of fast excitatory synaptic transmission in the CNS is mediated by AMPA-type glutamate receptors (AMPARs). The kinetic properties and $\mathrm{Ca}^{2+}$ permeability of the EPSCs are critically dependent on the subunit composition of the receptor subtypes targeted to postsynaptic sites. Molecular cloning has identified four AMPAR subunits (GluR1-GluR4) that can function as homomeric or heteromeric assemblies (Dingledine et al., 1999). Of these, GluR2 plays a particularly important role in determining channel properties, conferring a low $\mathrm{Ca}^{2+}$ permeability, relatively slow gating kinetics (Geiger et al., 1995; Jonas and Burnashev, 1995; Seeburg, 1996), and a low single-channel conductance (Swanson et al., 1997). Conversely, receptors lacking GluR2 display high $\mathrm{Ca}^{2+}$ permeability and a characteristic inwardly rectifying $I-V$ relationship attributable to voltagedependent block by intracellular spermine (Bowie and Mayer, 1995; Kamboj et al., 1995; Koh et al., 1995). Although mRNA for GluR2 is widely distributed in the CNS, the level of GluR2 subunit expression varies considerably between cell types, with many GABAergic interneurons expressing only low levels of GluR2 mRNA (Wisden and Seeburg, 1993; Geiger et al., 1995; Jonas and Burnashev, 1995).

Studies on neurons from the hippocampus and dorsal cochlear

Received Dec. 12, 2001; revised Feb. 28, 2002; accepted March 1, 2002.

This work was supported by a Wellcome Trust Programme grant to S.G.C.-C. S.J.L. was the recipient of a Wellcome Trust Travelling Fellowship. We thank Stephen Brickley, Laurence Cathala, Beverley Clark, Mark Farrant, Selina Mok, and Christine Gebhardt for helpful comments on this manuscript.

Correspondence should be addressed to Stuart G. Cull-Candy, Department of Pharmacology, University College London, Gower Street, London, WC1E 6BT, UK. E-mail: s.cull-candy@ucl.ac.uk or s.liu@ucl.ac.uk.

Copyright (ㄷ) 2002 Society for Neuroscience 0270-6474/02/223881-09\$15.00/0 nucleus have demonstrated that within individual cells, certain AMPAR subunits (including GluR2 and GluR4) can be selectively targeted to particular synapses (Rubio and Wenthold, 1997; Toth and McBain, 1998, 2000; Gardner et al., 1999). As a result, the EPSCs display different kinetic properties and $\mathrm{Ca}^{2+}$ permeabilities. Furthermore, we have found recently that in cerebellar stellate cells, the somatic AMPARs display properties characteristic of GluR2-containing assemblies, whereas the synaptic receptors appear to be composed predominantly of GluR2-lacking assemblies (Liu and Cull-Candy, 2000). From in situ hybridization studies and antibody labeling, cerebellar stellate cells express GluR3 subunits (Keinanen et al., 1990; Sato et al., 1993; Petralia et al., 1997). We have made use of the fact that intracellular spermine blocks $\mathrm{Ca}^{2+}$-permeable non-NMDA receptors to distinguish the presence of GluR2-containing AMPARs in these cells. The synaptic contribution of GluR2-containing AMPARs increases after high-frequency synaptic activity, whereas its contribution to somatic receptors is decreased after suppression of spontaneous action potential activity. Therefore, in stellate cells, the selective targeting of AMPAR subtypes appears to be controlled, at least in part, by neuronal activity.

This raises several key issues concerning the AMPAR subtypes present at the parallel fiber-to-stellate cell synapses. First, if targeting of particular AMPAR subtypes occurs under normal physiological conditions, then depending on the previous history of the synapse, variation might be expected in the degree of rectification of EPSCs. Second, in our previous studies, the presence of an activity-dependent change in the $\mathrm{Ca}^{2+}$ permeability of AMPARs was inferred from the change in the $I-V$ relationship. It was of interest to determine whether the predicted ionic perme- 
ability change could be directly verified in stellate cells. Third, on the basis of studies of native and recombinant AMPARs, an increased expression of GluR2-containing AMPARs at the synapse might be expected to influence EPSC kinetics (Geiger et al., 1995); we have examined this possibility.

\section{MATERIALS AND METHODS}

Electrophysiology. Sagittal or coronal cerebellar slices (200-250 $\mu \mathrm{m})$ were cut with a vibrating microslicer (DTK-1000; Dosaka EM Co., Kyoto, Japan) from the vermis of 18- to 20-d-old Sprague Dawley rats. This was performed in ice-cold slicing solution (in mM: $125 \mathrm{NaCl}, 2.5 \mathrm{KCl}, 1$ $\mathrm{CaCl}_{2}, 2 \mathrm{MgCl}_{2}, 26 \mathrm{NaHCO}_{3}, 1.25 \mathrm{NaH}_{2} \mathrm{PO}_{4}$, and 25 glucose, saturated with $95 \% \mathrm{O}_{2}-5 \% \mathrm{CO}_{2}, \mathrm{pH} 7.4$ ) as described previously (Liu and CullCandy, 2000). Slices were incubated in slicing solution at $30-31^{\circ} \mathrm{C}$ for 1 hr before recording. Sagittal slices were used for outside-out patch recordings, and coronal slices were used for experiments in which we measured synaptic currents. Whole-cell patch-clamp and outside-out patch recordings were made with an Axopatch 200A amplifier (Axon Instruments, Foster City, CA) in slices maintained in external solution (identical to slicing solution except that $1 \mathrm{mM} \mathrm{CaCl}_{2}$ and $2 \mathrm{mM} \mathrm{MgCl}_{2}$ were replaced with $2 \mathrm{mM} \mathrm{CaCl}_{2}$ and $1 \mathrm{mM} \mathrm{MgCl}_{2}$ ) in the presence of $\mathrm{GABA}_{\mathrm{A}}$ and NMDA receptor blockers [in $\mu \mathrm{M}: 20$ bicuculline methobromide, 100 picrotoxin, and 20-50 D-2-amino-5-phosphonopentanoic acid (D-AP-5)] at room temperature.

Synaptic currents. Recordings were made from visually identified neurons located in the outer two-thirds of the molecular layer. Stellate cells were identified by their ability to fire spontaneous action potentials in the cell-attached configuration and by the presence of spontaneous synaptic currents in the whole-cell configuration. Electrode resistances were 3-8 $\mathrm{M} \Omega$ when filled with internal solution [in mM: $95 \mathrm{CsF}, 45 \mathrm{CsCl}, 10$ Cs-HEPES, 10 Cs-EGTA, 2 NaCl, 2 ATP-Mg, 1 N-(2,6dimethylphenylcarbamoylmethyl) triethyl ammonium bromide (QX314), 5 TEA, $1 \mathrm{CaCl}_{2}$, and 0.1 spermine, $\mathrm{pH}$ 7.3]. Series resistance and whole-cell capacitance were $14.2 \pm 0.5 \mathrm{M} \Omega$ and $4.3 \pm 0.2 \mathrm{pF}(n=75)$, respectively. Series resistance was monitored throughout the experiment; if it changed by $>20 \%$ during the recording period, the experiment was discarded. Synaptic currents were recorded while the cell was voltageclamped at various potentials and were filtered at $10 \mathrm{kHz}$. EPSCs were evoked (at $0.33 \mathrm{~Hz}$ ) using a patch electrode filled with external solution positioned in the molecular layer. We applied 20-100 $\mu$ sec pulses of 5-30 V. Stimulation strength and duration were kept constant throughout the experiment. Miniature EPSCs (mEPSCs) were recorded in the presence of $1 \mu \mathrm{M}$ tetrodotoxin (TTX) in the external solution.

For analysis, EPSCs were filtered at $4 \mathrm{kHz}$ and digitized at $20 \mathrm{kHz}$. The decay time constants of synaptic currents were obtained by fitting the decay phase with single or double exponential equations using Microcal Origin version 6.0 (OriginLab, Northampton, MA). For the $I-V$ analysis, average traces at each holding potential were constructed by aligning on the point of fastest rise of a single event that had a smooth rise and decay phase (we typically obtained an average of 10-40 evoked EPSCs) using $\mathrm{N}$ version 4.0 (written by Stephen Traynelis, Emory University, Atlanta, GA). The mean EPSC amplitudes at negative potentials were fitted to a linear regression line. An $I-V$ relationship was considered linear if the EPSC amplitude at positive potentials fell along the line extrapolated from linearly fitting the data at negative potentials. An $I-V$ relationship was considered inwardly rectifying if the data at positive potentials fell consistently below the line.

Agonist-evoked currents in outside-out patches. Currents from outsideout patches subjected to voltage ramps (from -100 to $+80 \mathrm{mV} ; 42$ $\mathrm{mV} / \mathrm{sec}$ ) were measured before and during the application of $100 \mu \mathrm{M}$ kainate or $1 \mathrm{~mm}$ glutamate [with $100 \mu \mathrm{M}$ cyclothiazide (CTZ) present]. The agonist-evoked current in outside-out patches was obtained by subtracting the basal current in the absence of agonists from the current in the present of kainate or glutamate and cyclothiazide.

Rectification properties. In experiments in which the degree of rectification of the $I-V$ relationships of receptors was obtained from outsideout patches, we included $100 \mu \mathrm{M}$ spermine in the pipette solution (as described above). The rectification index was defined as the ratio of current amplitude at $+40 \mathrm{mV}$ versus the predicted value at $+40 \mathrm{mV}$. We extrapolated from linear fitting of the current between -20 and $+10 \mathrm{mV}$ to allow for the fact that patches gave outwardly rectifying currents.

$\mathrm{Ca}^{2+}$ permeability. The $\mathrm{I}-V$ relationships of agonist-evoked currents were compared in $\mathrm{Na}^{+}$-rich solution (in mM: $135 \mathrm{NaCl}, 5.4 \mathrm{KCl}, 1.8$ $\mathrm{CaCl}_{2}, 1 \mathrm{MgCl}_{2}, 5$ HEPES, pH 7.4) and in $\mathrm{Ca}^{2+}$-rich solution [in mM: 30
$\mathrm{CaCl}_{2}, 105 \mathrm{~N}$-methyl-D-glucamine (NMDG), 5 HEPES, pH 7.4]. In these experiments, we used a pipette solution that did not contain spermine, so that the maximum current was obtained at all potentials. The relative $\mathrm{Ca}^{2+}$ permeability of AMPA receptors, $\mathrm{P}_{\mathrm{Ca}} / \mathrm{P}_{\mathrm{Na}}$, was determined from the reversal potentials of the $I-V$ relationships of agonist-evoked currents in outside-out patches measured in $\mathrm{Na}^{+}$-rich solution and $\mathrm{Ca}^{2+}$-rich solution (as described by Geiger et al., 1995). The relative $\mathrm{Ca}^{2+}$ permeability was calculated using the following equation (Lewis, 1979): $\mathrm{P}_{\mathrm{Ca}} /$ $\mathrm{P}_{\mathrm{Na}}=1 / 4 \times \mathrm{a}_{\mathrm{Na}} / \mathrm{a}_{\mathrm{Ca}}\left\{\exp \left[\left(2 V_{\mathrm{revCa}}-V_{\mathrm{revNa}}\right) \mathrm{F} / \mathrm{RT}\right]+\exp \left[\left(V_{\mathrm{revCa}}-\right.\right.\right.$ $\left.\left.\left.V_{\text {revNa }}\right) \mathrm{F} / \mathrm{RT}\right]\right\}$, where $V_{\text {revCa }}$ and $V_{\text {revNa }}$ are the reversal potentials in $\mathrm{Ca}^{2+}$-rich and $\mathrm{Na}^{+}$-rich solutions and $\mathrm{a}_{\mathrm{Na}}$ and $\mathrm{a}_{\mathrm{Ca}}$ represent the activities of $\mathrm{Na}^{+}$and $\mathrm{Ca}^{2+}$ ions, respectively, in the external solutions. $V_{\text {revCa }}$ and $V_{\text {revNa }}$ values were corrected for liquid junction potentials of 6.3 and $9.2 \mathrm{mV}$, respectively, calculated using Clampex version 8.0 (Axon Instruments, Union City, CA). Activity coefficients used for the calculation of $\mathrm{a}_{\mathrm{Na}}$ and $\mathrm{a}_{\mathrm{Ca}}$ were 0.75 and 0.55 , respectively, as estimated by Geiger et al. (1995)

All values are expressed as mean \pm SEM. Statistical significance was assessed by two-tailed Student's $t$ test. Cyclothiazide, QX314, D-AP-5, kainate, bicuculline methobromide, and TTX were obtained from Tocris (Bristol, UK), and spermine, L-glutamate, and picrotoxin were from Sigma (St. Louis, MO).

\section{RESULTS}

At the parallel fiber input to stellate cells, minimal stimulation generates EPSCs that are mediated solely by non-NMDA receptors (Clark and Cull-Candy, 2002). Our previous studies have made use of the fact that intracellular spermine blocks $\mathrm{Ca}^{2+}$. permeable (GluR2-lacking) receptors at depolarized potentials (Bowie and Mayer, 1995; Kamboj et al., 1995; Koh et al., 1995; Rozov and Burnashev, 1999) to identify the presence of GluR2containing AMPARs in these cells. At low levels of synaptic activity, EPSCs display inwardly rectifying $I-V$ relationships consistent with the presence of GluR2-lacking AMPARs at these synapses (Liu and Cull-Candy, 2000). After high-frequency synaptic activity, the $I-V$ relationship of these EPSCs becomes linear, implying a change in their subunit composition and $\mathrm{Ca}^{2+}$ permeability.

In the present study, we addressed the issue of whether the $I-V$ relationship, and hence GluR2 targeting, varied between synapses as might be expected if this process occurs in vivo. In particular, we examined whether the degree of rectification was related to the rate of spontaneous synaptic activity. We also examined whether changes in the $I-V$ relationship of currents in these cells were directly associated with a change in $\mathrm{Ca}^{2+}$ permeability and whether the targeting of GluR2 to the synapse caused obvious changes in the properties of EPSCs.

\section{Synaptic currents display a wide range of rectification values}

We first examined the possibility that synaptic activity modulates the expression of GluR2-containing AMPARs under normal conditions. If the targeting of the AMPAR subtype is a dynamic process (and does not occur in an all-or-none manner), then differences would be expected in the degree of rectification displayed by different synapses. To determine whether such variation occurred between stellate cells in our slices, we examined evoked EPSCs over a range of holding potentials in cells from 46 rats. In addition, we attempted to determine whether the AMPAR subtype expressed was related to the level of spontaneous synaptic activity. In cerebellar stellate cells, the spontaneous synaptic currents and evoked EPSCs arise from a single type of afferent input: the parallel fibers (granule cell axons). We reasoned that in cells in which spontaneous EPSCs (sEPSCs) occurred at a high rate, a given synapse would be more likely to have experienced spontaneous 
A



C

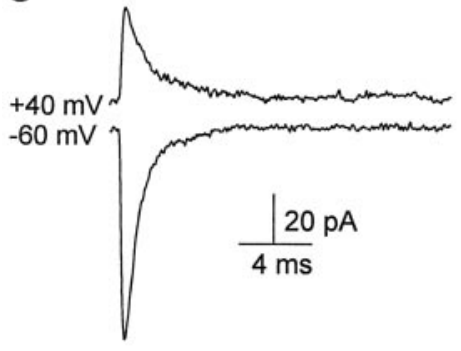

B

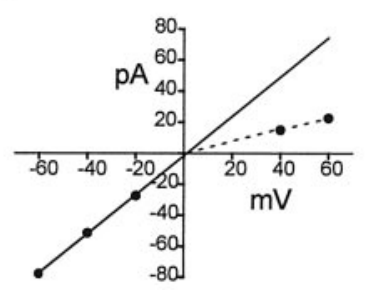

D

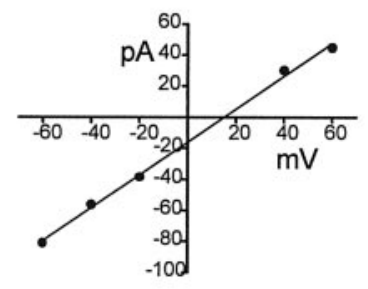

$E$

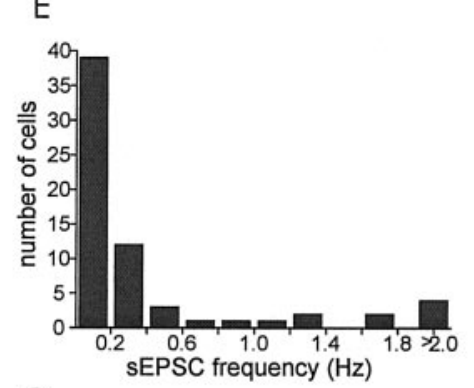

$G$



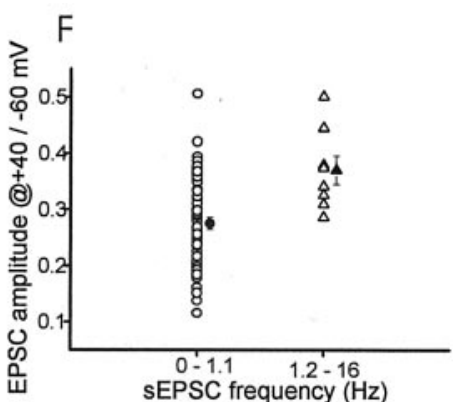

$\mathrm{F}$

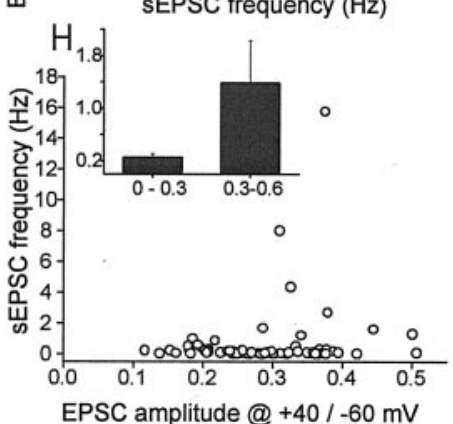

Figure 1. Synaptic currents in cerebellar stellate cells displayed various degrees of rectification. $A, B$, Data from a cell that displayed a spontaneous EPSC rate of $0.62 \mathrm{~Hz}$. $A$, Mean evoked EPSC traces at +40 and $-60 \mathrm{mV}(100 \mathrm{~mm}$ spermine present in the pipette solution). $B$, The synaptic current displayed an inwardly rectifying $I-V$ relationship. The solid line is a linear regression line fitted to the data points at hyperpolarized potentials, and the dashed line connects the data points at depolarized potentials. The EPSC amplitude at depolarized potentials fell below the solid line, indicative of inward rectification. $C, D$, Data from a stellate cell in which spontaneous EPSCs occurred at $15.7 \mathrm{~Hz}$. $C$, Mean evoked EPSCs at +40 and $-60 \mathrm{mV}$. $D$, The $I-V$ relationship of synaptic currents shown in $C$. The data points at depolarized potentials fell along the solid line, indicating a linear $I-V$ relationship. $E$, Histogram of sEPSC frequency $(n=65$ cells; mean, $0.72 \pm 0.28 \mathrm{~Hz}) . F$, Ratio of EPSC amplitudes at +40 versus $-60 \mathrm{mV}\left(\mathrm{R}_{+40 /-60}\right)$ determined from cells displaying high sEPSC frequency (open triangles) and low sEPSC frequency (open circles). Cells with a high rate of sEPSCs had a higher mean $\mathrm{R}_{+40 /-60}$ value ( filled triangle, $n=8$ ) than cells with low sEPSC frequency ( filled circle; $n=27 ; p<0.005$ ). $G$, Histogram of the ratio of the EPSC amplitudes at +40 versus $-60 \mathrm{mV}(n=65$ cells; mean, $0.29 \pm 0.01)$. $H$, Relationship between sEPSC frequency and the ratio of EPSC amplitudes at +40 versus $-60 \mathrm{mV}$. Inset, Average sEPSC frequency in cells in which evoked EPSCs gave $\mathrm{R}_{+40 /-60}$ values of $<0.3(n=38)$ and $>0.3(n=27)(p<$ $0.05)$.

presynaptic activity than in cells in which spontaneous EPSC frequency was low. Thus, if the activity-induced targeting of GluR2-containing AMPARs occurred under normal conditions, the expression of GluR2 at the synapse would be expected to correlate with the rate of spontaneous EPSCs in the cell and to depend on the previous history of the synapse.

Stellate cells generally displayed a low rate of spontaneous synaptic activity (Fig. $1 E$ ); the average spontaneous EPSC frequency was $0.72 \pm 0.28 \mathrm{~Hz}(n=65$ cells $)$. In 57 cells, the frequency of spontaneous EPSCs was $<1.1 \mathrm{~Hz}$, with a mean frequency of $0.18 \pm 0.03 \mathrm{~Hz}$. In such cells, the amplitude of the synaptic current was reduced at depolarized potentials, and the $I-V$ relationship of evoked EPSCs displayed clear inward rectification, indicative of the presence of synaptic GluR2-lacking AMPARs. An example of this is depicted in Figure $1 A, B$ (EPSCs at +40 and $-60 \mathrm{mV}$; spontaneous EPSC frequency, 0.62 $\mathrm{Hz}$ ). Among the 65 cells examined, 8 displayed a rate of spontaneous EPSC activity that was markedly higher, with a mean frequency of $4.6 \pm 1.8 \mathrm{~Hz}(n=8 ; p<0.0001)$. Figure $1 C, D$ illustrates data from a cell in which the spontaneous EPSCs occurred at 15.7 $\mathrm{Hz}$. The synaptic currents in these cells gave linear $I-V$ plots, indicating the absence of polyamine block at depolarized potentials and suggesting the presence of GluR2-containing $\left(\mathrm{Ca}^{2+}\right.$ impermeable) AMPARs. The ratio of EPSC amplitude at +40 versus $-60 \mathrm{mV}, \mathrm{R}_{+40 /-60}$, was subsequently used to determine the relative rectification behavior of synaptic currents. The value for $\mathrm{R}_{+40 /-60}$ from cells that displayed a higher rate of spontaneous EPSC activity (sEPSC frequency of $>1.2 \mathrm{~Hz} ; \mathrm{R}_{+40 /-60}=0.37 \pm$
$0.03 ; n=8$ ) was significantly greater than that from those cells in which sEPSC frequency was low $\left(\mathrm{R}_{+40 /-60}=0.28 \pm 0.01 ; n=57\right.$; $p<0.005$ ) (Fig. 1F). Thus, synaptic currents in cells that displayed a high rate of spontaneous EPSCs appeared to be mediated largely by GluR2-containing receptors, consistent with the idea that increased spontaneous synaptic activity is related to the expression of GluR2 at these synapses.

We obtained a wide range of values for the ratio of EPSC amplitude at +40 versus $-60 \mathrm{mV}$ in stellate cells. As can be seen from Figure $1 G$, these ranged from 0.11 to 0.51 , with an average value of $0.29 \pm 0.01(n=65$ cells $)$. Synaptic currents that displayed inward rectification $\left(\mathrm{R}_{+40 /-60}<0.30\right.$; mean $\mathrm{R}_{+40 /-60}=$ $0.23 \pm 0.01 ; n=38$ ) were obtained from cells in which the rate of sEPSCs was low (sEPSC frequency of $<1.1 \mathrm{~Hz}$ for 37 cells and $1.67 \mathrm{~Hz}$ for 1 cell; mean sEPSC frequency, $0.25 \pm 0.05 \mathrm{~Hz}$ ) (Fig. $1 H)$. In contrast, cells from which synaptic currents gave a high $\mathrm{R}_{+40 /-60}$ value $\left(\mathrm{R}_{+40 /-60}>0.30\right.$; mean $\mathrm{R}_{+40 /-60}=0.37 \pm 0.01$; $n=27$ ) exhibited a wide range of spontaneous EPSC frequencies (sEPSC frequency of $<0.6 \mathrm{~Hz}$ for 20 cells and $1.2-16 \mathrm{~Hz}$ for 7 cells), with a higher mean sEPSC frequency value $(1.38 \pm 0.65$ $\mathrm{Hz} ; p<0.05$ ) (Fig. $1 F, H)$. This would be consistent with the notion that the rectification property of synaptic currents was related not only to the spontaneous synaptic activity at the time of measurements but also to the previous history of the synapse. These observations are in keeping with the idea that surface expression of GluR2-containing receptors varies between stellate cell synapses and is related to the level of intrinsic synaptic activity. 

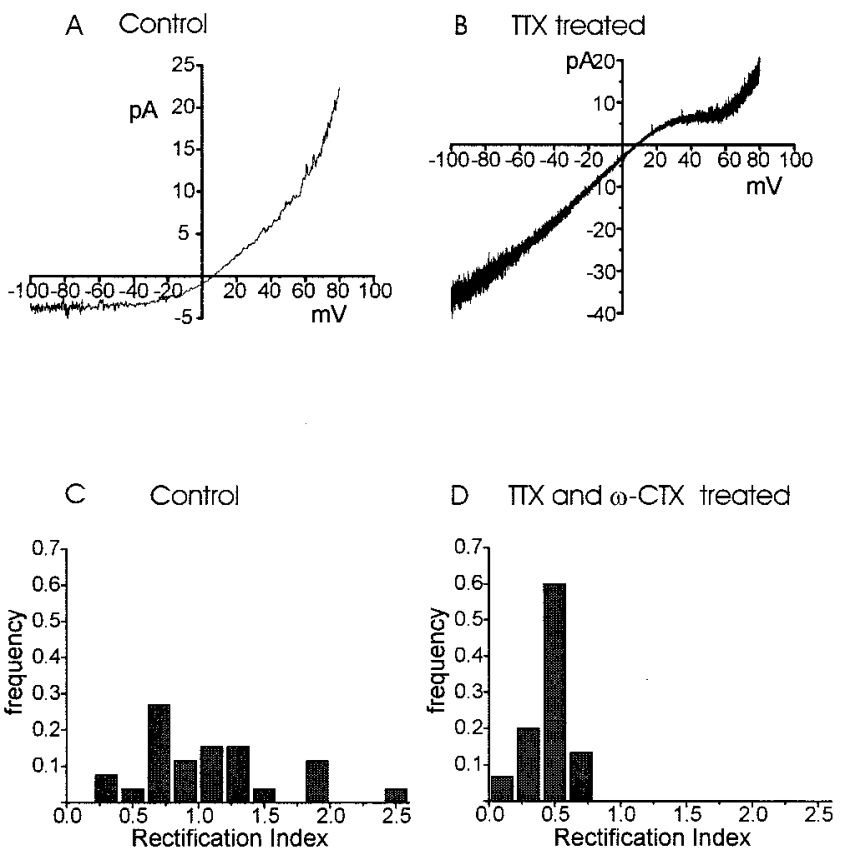

Figure 2. Rectification properties of kainate-evoked currents in outsideout patches excised from the soma of stellate cells. $A$, Outwardly rectifying $I-V$ relationship of kainate-evoked currents in an outside-out patch from a control cell. Spermine $(100 \mu \mathrm{M})$ was included in the pipette solution. $B$, The agonist-evoked current in an outside-out patch excised from a TTX-treated stellate cell exhibited an inwardly rectifying $I-V$ relationship. The slice was treated with $1 \mu \mathrm{M}$ TTX for $>2 \mathrm{hr}$ and subsequently washed before the recording. $C$, Histogram of the rectification index of kainate-evoked currents in outside-out patches from control cells (defined as the ratio of current amplitude at $+40 \mathrm{mV}$ vs the predicted linear value at $+40 \mathrm{mV})$. The rectification index was $1.1 \pm 0.1(n=26$ patches). $D$, Histogram of the rectification index of agonist-evoked currents in outside-out patches from TTX-treated cells $(n=8$ patches) and cells treated with $\omega$-conotoxin $(\omega$-CTX) $(500 \mathrm{~nm} \omega$-conotoxin GVIA for $>2 \mathrm{hr}$ before recording; $n=7$ patches). A current trace was shown in our previous publication (Liu and Cull-Candy, 2000).

\section{Decreased $\mathrm{Ca}^{2+}$ permeability accompanies the change in rectification of extrasynaptic AMPARs}

The activity-dependent change in the rectification properties of the synaptic current (from inwardly rectifying to linear) implies a decrease in the $\mathrm{Ca}^{2+}$ permeability of the synaptic AMPARs (Liu and Cull-Candy, 2000). However, it is difficult to test for this directly by examining EPSCs in various levels of external $\mathrm{Ca}^{2+}$, because this procedure greatly alters transmitter release. While synaptic activity triggers the targeting of GluR2-containing receptors to the synapses, spontaneous action potential activity facilitates their expression in the soma (the majority of stellate cells fire action potentials spontaneously in cerebellar slices in the absence of excitatory synaptic inputs [Hausser and Clark, 1997]). Our previous experiments have suggested that $\mathrm{Ca}^{2+}$ entry via $\mathrm{N}$-type calcium channels increases the expression of extrasynaptic GluR2-containing AMPA receptors in the soma (Liu and CullCandy, 2000). We therefore examined the AMPAR channels in outside-out patches excised from the soma of stellate cells to determine whether their change in rectification properties was accompanied by decreased permeability to $\mathrm{Ca}^{2+}$.

As shown in Figure $2 A$, bath application of the AMPAR agonist kainate $(100 \mu \mathrm{M})$ to outside-out patches evoked steadystate currents with outwardly rectifying $I-V$ relationships. A similar outwardly rectifying $I-V$ relationship was described for
Table 1. Rectification index and calcium permeability of AMPARs in outside-out patches from control and TTX-treated stellate cells

\begin{tabular}{lrl} 
& \multicolumn{1}{l}{ Control } & TTX treated \\
\hline Rectification & & \\
$\quad$ index & $1.1 \pm 0.1(n=26)$ & $0.52 \pm 0.08(n=8)$ \\
$\mathrm{P}_{\mathrm{Ca}} / \mathrm{P}_{\mathrm{Na}}$ & $0.25 \pm 0.11(n=4)$ & $1.64 \pm 0.52(n=5)$ \\
\hline
\end{tabular}

Rectification index values and $\mathrm{P}_{\mathrm{Ca}} / \mathrm{P}_{\mathrm{Na}}$ were significantly different between control and TTX-treated cells ( $p<0.01$ and $p<0.04$, respectively).

steady-state currents in patches from chick nMAG neurons and in cells expressing recombinant GluR2-containing receptors (Verdoorn et al., 1991; Raman and Trussell, 1995). In 26 patches examined, the average rectification index value was $1.1 \pm 0.1(n=$ 26) (Fig. 2C; Table 1). This suggests that GluR2-containing AMPARs are present in the soma. After TTX treatment $(1 \mu \mathrm{M})$ for $>2 \mathrm{hr}$, the agonist-evoked currents displayed an inwardly rectifying $I-V$ relationship (Fig. $2 B$ ), and the rectification index was $0.52 \pm 0.08(n=8)$ (Fig. $2 D$; Table 1$)$.

To test whether an increased $\mathrm{Ca}^{2+}$ permeability accompanied this change, we compared agonist-evoked currents in patches from control and TTX-treated cells in $\mathrm{Na}^{+}$-rich $(135 \mathrm{~mm} \mathrm{NaCl})$ and $\mathrm{Ca}^{2+}$-rich $\left(30 \mathrm{mM} \mathrm{CaCl}_{2}\right)$ external solutions (see Materials and Methods). The relative $\mathrm{Ca}^{2+}$ permeability was determined from reversal potentials of these currents in $\mathrm{Na}^{+}$-rich and $\mathrm{Ca}^{2+}$ rich solutions. Because the presence of intracellular spermine does not alter the reversal potential of agonist-evoked currents regardless of whether it is mediated by $\mathrm{Ca}^{2+}$-permeable or $\mathrm{Ca}^{2+}$ impermeable AMPARs (Rozov and Burnashev, 1999), spermine was not included in the pipette solution so as to minimize voltagedependent block of $\mathrm{Ca}^{2+}$-permeable receptors. As shown in Figure $3 A$, the current in control patches reversed at more hyperpolarized potentials in $\mathrm{Ca}^{2+}$-rich $(-51.6 \pm 8.8 \mathrm{mV} ; n=4)$ than in $\mathrm{Na}^{+}$-rich $(2.2 \pm 3.2 \mathrm{mV})$ solution. In contrast, patches from TTX-treated cells displayed reversal potentials of $-14.8 \pm$ $6.1 \mathrm{mV}\left(n=5 ; p<0.01\right.$ compared with the $V_{\text {revCa }}$ value in control patches) in $\mathrm{Ca}^{2+}$-rich solution (Fig. $3 B$ ), quite close to the value obtained in $\mathrm{Na}^{+}$-rich solution $(-1.1 \pm 3.6 \mathrm{mV})$ in these same patches. The inwardly rectifying AMPARs (in TTX-treated cells) therefore displayed a greater degree of $\mathrm{Ca}^{2+}$ permeability.

The reversal potentials were determined from $I-V$ relationships and corrected for the junction potential of $9.2 \mathrm{mV}$ in $\mathrm{Na}^{+}$-rich solution and $6.3 \mathrm{mV}$ in $\mathrm{Ca}^{2+}$-rich solution. From these experiments, we estimated the relative $\mathrm{Ca}^{2+}$ permeability, $\mathrm{P}_{\mathrm{Ca}^{2+}} / \mathrm{P}_{\mathrm{Na}^{+}}$, of the AMPA receptors (see Materials and Methods). In patches from TTX-treated cells, our estimate for $\mathrm{Ca}^{2+}$ permeability $\left(\mathrm{P}_{\mathrm{Ca}} / \mathrm{P}_{\mathrm{Na}}=1.64 \pm 0.52 ; n=5\right)$ was at least six times higher than in patches from control cells $\left(\mathrm{P}_{\mathrm{Ca}} / \mathrm{P}_{\mathrm{Na}}=0.25 \pm 0.11 ; n=4 ; p<\right.$ 0.04) (Fig. 3C). It is of note that the very low (but nonzero) permeability of NMDG via AMPA receptors $\left(\mathrm{P}_{\mathrm{NMDG}} / \mathrm{P}_{\mathrm{Cs}}=\right.$ 0.01-0.02) (Burnashev et al., 1996) may slightly alter the calculated permeability ratios. Thus, the activity-dependent increase in the rectification index was indeed accompanied by a decreased $\mathrm{Ca}^{2+}$ permeability of the somatic AMPAR channels (Table 1).

\section{Time course of synaptic currents}

Having found that the expression of GluR2-containing AMPARs at the synapse was related to higher spontaneous synaptic activity, we examined whether the presence of GluR2 modified the time course of the EPSC at these synapses. The EPSC decay time was fitted either with a single exponential or by the sum of two exponential functions. The weighted decay time constant of syn- 
A Control



B TTX treated
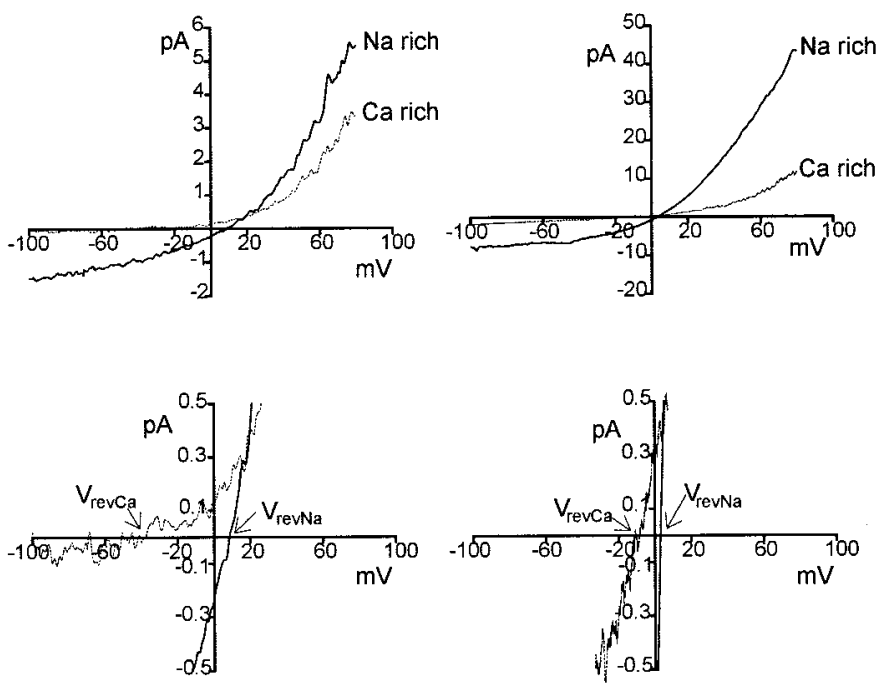

C

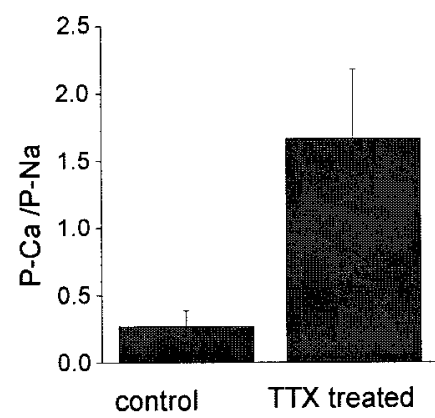

Figure 3. High $\mathrm{Ca}^{2+}$ permeability of AMPARs in outside-out patches from TTX-treated cells. The $I-V$ relationships of agonist-evoked currents in an outside-out patch were measured in $\mathrm{Na}^{+}$-rich solution and in $V_{\text {revCa }}$, were determined from their $I-V$ plots. $A, I-V$ relationship of a response from an outside-out patch from control cells. The currents reversed at a more hyperpolarized potential in $\mathrm{Ca}^{2+}$-rich solution $(30 \mathrm{mM}$ $\mathrm{CaCl}_{2}$; dashed line) than in $\mathrm{Na}^{+}$-rich solution $(135 \mathrm{~mm} \mathrm{NaCl}$; solid line $)$, indicating a lower permeability to $\mathrm{Ca}^{2+}$ than to $\mathrm{Na}^{+}$. Bottom, The same $I-V$ relationship as shown at the top, but on an expanded scale. Spermine was not included in the pipette solution. $B, I-V$ relationship of a response from a patch from TTX-treated cells. The reversal potential of the agonist-evoked current in $\mathrm{Ca}^{2+}$-rich solution is close to the reversal potential in $\mathrm{Na}^{+}$-rich solution. $C$, The $\mathrm{Ca}^{2+}$ permeability of AMPARs in outside-out patches from control cells $(n=4)$ was significantly lower than that from TTX-treated cells $(n=5 ; p<0.04)$. The $\mathrm{Ca}^{2+}$ permeability, $\mathrm{P}_{\mathrm{Ca}} / \mathrm{P}_{\mathrm{Na}}$, was calculated from the reversal potentials in $\mathrm{Na}^{+}$-rich and $\mathrm{Ca}^{2+}$-rich solutions (as described in Materials and Methods).

aptic currents at $-60 \mathrm{mV}$, in cells that displayed a high rate of spontaneous synaptic activity $\left(4.6 \pm 0.03 \mathrm{~Hz} ; \mathrm{R}_{+40 /-60}=0.37 \pm\right.$ $0.03 ; n=8)$, was $0.72 \pm 0.06 \mathrm{msec}$. The cells in which both the rate of spontaneous EPSCs and the $\mathrm{R}_{+40 /-60}$ value were low $\left(0.18 \pm 0.07 \mathrm{~Hz}, p<0.03 ; \mathrm{R}_{+40 /-60}=0.23 \pm 0.01, p<0.001 ; n=\right.$ 8 ) displayed EPSCs with a weighted decay time constant of $0.77 \pm 0.06 \mathrm{msec}(p=0.59)$. This suggests that EPSCs displaying different rectification properties have a similar decay time course in these cells.

Because the decay time constant varied among stellate cells (ranging from 0.50 to $1.1 \mathrm{msec}$ ), we examined the effects of GluR2 on the time course of the EPSC at the same synapse by making use of the fact that spermine selectively blocks GluR2-lacking $\mathrm{Ca}^{2+}$-rich solution. The reversal potentials of these currents, $V_{\text {revNa }}$ and
A

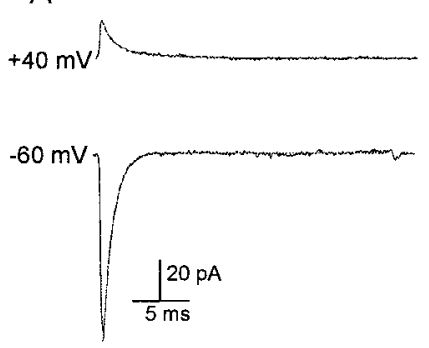

B

C
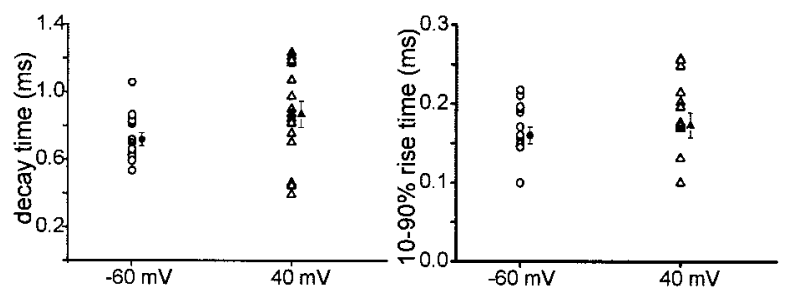

Figure 4. EPSCs mediated by GluR2-containing and by GluR2-lacking AMPARs have similar kinetic properties. $A$, At $-60 \mathrm{mV}$, EPSCs were mediated by a mixed population of AMPARs; the $10-90 \%$ rise time was $0.20 \mathrm{msec}$. The decay time course (fitted with the single exponential function) gave a time constant of $0.86 \mathrm{msec}$. At $+40 \mathrm{mV}$, EPSCs were mediated by GluR2-containing AMPARs. The $10-90 \%$ rise time of the synaptic current was $0.18 \mathrm{msec}$. The decay time course was best fitted with the two exponential functions. The fast component (96\% of peak amplitude) had a decay time constant of $0.81 \mathrm{msec}$; the slow component was $3.28 \mathrm{msec}$. The weighted decay time constant was $0.90 \mathrm{msec}$. B, Synaptic currents at -60 and $+40 \mathrm{mV}$ normalized to their peak current amplitude to allow comparison of decay time. In this example, the decay time was marginally slower at $+40 \mathrm{mV}$. $C$, The decay time constant of synaptic currents at $-60 \mathrm{mV}$ was not significantly different from that at $+40 \mathrm{mV}$ ( $p=0.12$ by paired $t$ test; $n=14$ cells). Open circles and open triangles are individual data, and filled circle and filled triangle are average values \pm SE. $D$, Summary of the $10-90 \%$ rise time of synaptic currents at -60 and +40 $\mathrm{mV}(p=0.37$ by paired $t$ test; $n=14$ cells $)$.

AMPARs at depolarized potentials. This allowed us to compare EPSCs at $+40 \mathrm{mV}$, which are expected to be mediated only by GluR2-containing receptors, with currents at $-60 \mathrm{mV}$ mediated by a mixed AMPAR population. As a control, we first tested whether EPSCs mediated primarily by GluR2-containing receptors displayed different decay kinetics when measured at these two potentials. In cells that displayed a high rate of spontaneous EPSCs, the weighted decay time constant of EPSCs at $+40 \mathrm{mV}$ was $0.84 \pm 0.13 \mathrm{msec}(n=8)$, not significantly different from that at $-60 \mathrm{mV}$ ( $p=0.38$ by paired $t$ test).

We subsequently examined the kinetic properties of EPSCs recorded from cells in which spontaneous EPSC frequency occurred at a low rate $(0.15 \pm 0.05 \mathrm{~Hz} ; n=14)$. An example is illustrated in Figure $4 A$. The time course of evoked EPSCs at both positive and negative potentials was fitted either with a single exponential or by the sum of two exponential functions. In 5 of the 14 cells, the EPSCs at $-60 \mathrm{mV}$ were well fitted with a single exponential decay. In the other nine cells, the decay time course was best fitted by the sum of two components. The fast component made up $95 \pm 2 \%$ of the peak amplitude and decayed with a time constant of $0.67 \pm 0.03 \mathrm{msec}$; the slower component decayed with a time constant of $2.42 \pm 0.31 \mathrm{msec}$ (Fig. 4). The weighted mean decay time constant was $0.72 \pm 0.04 \mathrm{msec}(n=$ 14), and the average $10-90 \%$ rise time was $0.16 \pm 0.01 \mathrm{msec}$ (Fig. $4 C, D)$. 
At $+40 \mathrm{mV}$, in 9 of the 14 cells, the decay time course was fitted by two exponential functions: a fast component with a decay time constant of $0.66 \pm 0.08 \mathrm{msec}(96 \pm 2 \%$ of the peak amplitude) and a slower component with a decay time constant of $3.38 \pm 0.47$ msec (Fig. 4A). The decay of the synaptic current in the other five cells could be well fitted by a single exponential function. The mean weighted decay time constant for all cells was $0.87 \pm 0.08$ msec $(n=14)$; this was not significantly different from the decay time constant at $-60 \mathrm{mV}(p=0.12$ by paired $t$ test) (Fig. $4 B, C)$. The small difference depicted in Figure $4 B$ was not significant in relation to the data as a whole. The average 10-90\% rise time was $0.17 \pm 0.02 \mathrm{msec}$ (Fig. 4D). These observations suggest that targeting of GluR2-containing AMPARs to the synapse did not significantly alter the decay time course of the synaptic current in stellate cells.

\section{Effects of cyclothiazide on inward and outward synaptic currents}

Cyclothiazide suppresses the desensitization and deactivation of AMPA receptors and increases their apparent affinity for glutamate (Patneau et al., 1993; Trussell et al., 1993; Partin et al., 1996; Yamada and Turetsky, 1996). However, these effects depend on the subunit isoforms involved in AMPA receptor formation. Each subunit can exist as flip or flop splice variants (Sommer et al., 1991; Seeburg, 1993; Hollmann and Heinemann, 1994); the sensitivity to cyclothiazide varies between flip and flop (Partin et al., 1994, 1996). For receptors containing GluR $1_{\text {flip }}$ subunits, deactivation is markedly slowed by cyclothiazide (Partin et al., 1996). Furthermore, several studies have suggested that potentiation of AMPARs by cyclothiazide may also depend on the identity of the AMPAR subunits forming the receptor (Yamada and Turetsky, 1996; Dai et al., 2001), with the extent of potentiation being significantly reduced by hetero-oligomerization (Cotton and Partin, 2000). We examined evoked and miniature EPSCs to determine whether the involvement of the GluR2 subunit isoform modified the influence of cyclothiazide on the synaptic current properties. We included spermine in the pipette solution and compared the effects of cyclothiazide on EPSCs mediated by different complements of $\mathrm{Ca}^{2+}$-impermeable and $\mathrm{Ca}^{2+}$ permeable receptor subtypes at the stellate cell synapse.

Evoked EPSCs were examined at +40 and $-40 \mathrm{mV}$ in control conditions and in the presence of $100 \mu \mathrm{M}$ cyclothiazide (Fig. $5 A, B)$. As expected, the decay time course of EPSCs was slowed in the presence of CTZ both at $+40 \mathrm{mV}$ (weighted decay time constant, $\tau$, changing from $1.0 \pm 0.13$ to $6.57 \pm 1.35 \mathrm{msec} ; n=5$; $p<0.02$ by paired $t$ test) and at $-40 \mathrm{mV}$ (from $0.97 \pm 0.16$ to $2.58 \pm 0.35$ msec; $n=5 ; p<0.02$ ) (Fig. 5; Table 2). Because the receptors composed of flop isoforms are less sensitive to modulation of their desensitization and deactivation kinetics by cyclothiazide than flip splicing variants (Patneau et al., 1993; Partin et al., 1996; Yamada and Turetsky, 1996), this result is consistent with the idea that EPSCs are mediated, at least in part, by flip isoform-containing AMPARs at these synapses. Furthermore, the change in decay time was more pronounced at positive potentials $\left(\tau_{\mathrm{CTZ}} / \tau_{\text {control }}=6.6\right)$ than at negative potentials $\left(\tau_{\mathrm{CTZ}} /\right.$ $\tau_{\text {control }}=2.66 ; p<0.02$ by paired $t$ test, comparing $\tau$ values at -40 $\mathrm{mV}$ in the presence of cyclothiazide with those at $+40 \mathrm{mV}$ ) (Fig. $5 A, B$; Table 2). Thus, it is possible that more flop isoforms were present in $\mathrm{Ca}^{2+}$-permeable receptors than in GluR2-containing receptors.

Cyclothiazide affected EPSC amplitude differently at positive and negative potentials. At $+40 \mathrm{mV}$, when the current is expected
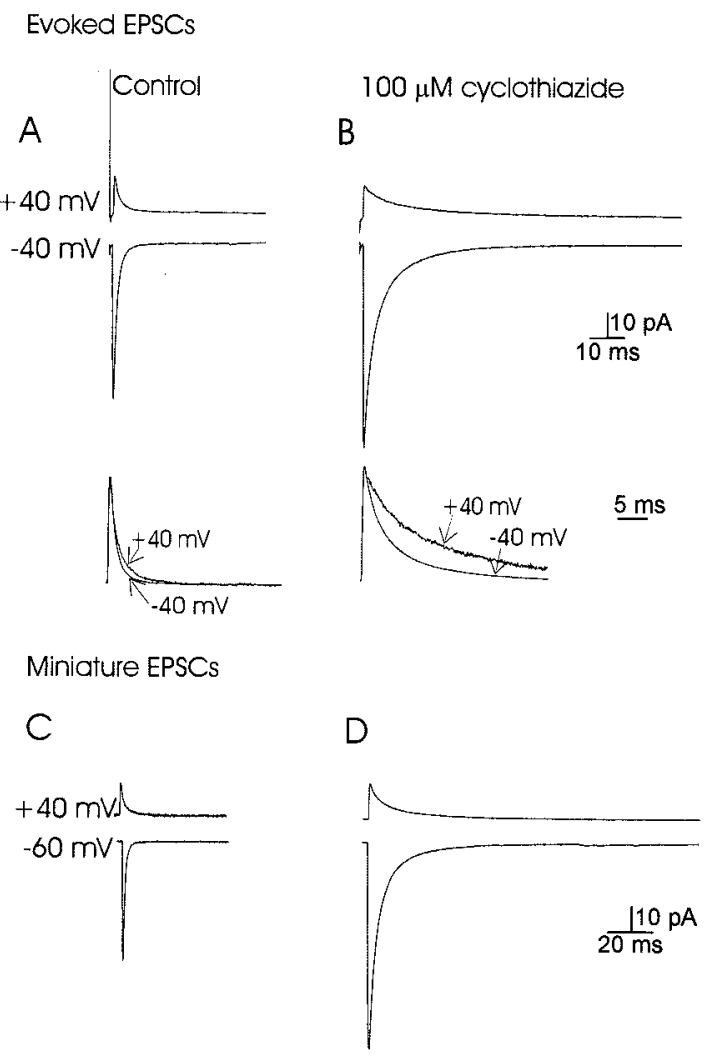

Figure 5. Effect of cyclothiazide on the time course and amplitude of EPSCs and miniature EPSCs at hyperpolarized and depolarized potentials. $A, B$, The evoked EPSCs were recorded at -40 and $+40 \mathrm{mV}$ before $(A)$ and during $(B)$ perfusion of $100 \mu \mathrm{M}$ cyclothiazide. The bottom traces show EPSCs normalized to the peak current amplitude at -40 and +40 $\mathrm{mV}$. Note the difference in the effect on time course at -40 and $+40 \mathrm{mV}$. $C, D$, Miniature EPSCs were recorded at -60 and $+40 \mathrm{mV}$ in the presence of $1 \mu \mathrm{M}$ TTX before $(C)$ and during $(D)$ bath application of 100 $\mu \mathrm{M}$ cyclothiazide. Note the increase in amplitude at $-60 \mathrm{mV}$ and the absence of change at $+40 \mathrm{mV}$ after cyclothiazide treatment. All traces were average EPSCs of 60-90 evoked EPSCs and of 30-120 miniature EPSCs.

to be mediated by GluR2-containing receptors, the EPSC amplitude was unaffected $(23.1 \pm 2.3 \mathrm{pA}$ in controls and $22.0 \pm 3.2 \mathrm{pA}$ in cyclothiazide). In contrast, at $-40 \mathrm{mV}$, the amplitude was increased by $\sim 50 \%$ (from $-82 \pm 17 \mathrm{pA}$ to $-122 \pm 22 \mathrm{pA} ; n=5$; $p<0.02$ by paired $t$ test) (Fig. $5 A, B$; Table 2). Because cyclothiazide affects several properties of AMPARs, its effects on EPSCs could be complicated (see Discussion). One possibility would be that receptors mediating EPSCs at negative potentials (mixed receptor population) desensitize more rapidly than those at positive potentials (GluR2-containing receptors); slowing desensitization kinetics by cyclothiazide could cause an increase in EPSC amplitude at hyperpolarized potentials. Work on both recombinant and native receptors has shown that the receptors composed of flop isoforms exhibit rapid desensitization compared with flip isoforms (Mosbacher et al., 1994; Geiger et al., 1995; Lambolez et al., 1996). Therefore, this could result from more flop isoforms present in $\mathrm{Ca}^{2+}$-permeable receptors than in GluR2-containing receptors, which is consistent with our observation that cyclothiazide produced a more pronounced change in decay time at positive than at negative potentials.

It is worth noting that the percentage increase in evoked EPSC amplitude at $-40 \mathrm{mV}$ is likely to give an underestimate of the 
Table 2. Effects of cyclothiazide $(100 \mu \mathrm{M})$ on the properties of evoked synaptic currents at -40 and $+40 \mathrm{mV}$




properties at -40 and $+40 \mathrm{mV}$ in the same condition: $\dagger p<0.02$, $\dagger \uparrow p<0.005$ by a two-tailed paired $t$ test. $n=5$.

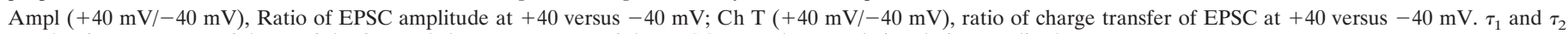
are the time constants of decay of the fast and slow components of the EPSC; $\mathrm{a}_{1}$ and $\mathrm{a}_{2}$ are their relative amplitudes.

effects of cyclothiazide on GluR2-lacking receptors. Thus, we subtracted the synaptic current at $+40 \mathrm{mV}$ (which was mediated by GluR2-containing receptors) from the EPSC at $-40 \mathrm{mV}$ (mixed receptor population) to obtain a current mediated by GluR2-lacking receptors. In the absence of the GluR2-containing component of the EPSC, the percentage increase of the current amplitude from GluR2-lacking receptors was $\sim 60 \%$ (from $-63.5 \pm 18.1$ to $-101.0 \pm 14.0 \mathrm{pA} ; p<0.02$ by paired $t$ test), and the weighted decay time constants increased from $0.73 \pm 0.09$ to $2.16 \pm 0.32 \mathrm{msec}(n=5 ; p<0.01$ by paired $t$ test $)$.

To exclude the possibility that the effects we observed could simply be ascribed to an alteration in transmitter release properties (Diamond and Jahr, 1995; Ishikawa and Takahashi, 2001), we examined mEPSCs (in $1 \mu \mathrm{M}$ TTX) in the presence and absence of cyclothiazide. The frequency of mEPSCs appeared to change from $0.043 \pm 0.009$ to $0.265 \pm 0.109 \mathrm{~Hz}(n=4 ; p=0.13$ by paired $t$ test), indicating some presynaptic action of cyclothiazide. However, as found with the evoked EPSCs, the decay time course of mEPSCs was prolonged at both $+40 \mathrm{mV}$ and $-60 \mathrm{mV}$ after application of cyclothiazide (Fig. 5C,D). Furthermore, their amplitude was increased by $56 \%$, from $-55.2 \pm 2.7$ to $-85.9 \pm 5.0$ $\mathrm{pA}$ at $-60 \mathrm{mV}(n=4 ; p<0.0001$ by paired $t$ test), whereas at $+40 \mathrm{mV}$, mEPSC amplitude remained unaltered $(19.5 \pm 2.7$ and $21.0 \pm 4.4 \mathrm{pA})$. The fact that cyclothiazide has similar effects on evoked EPSC and mEPSC properties in stellate cells suggests that the changes we observed were attributable primarily to its postsynaptic actions.

\section{DISCUSSION}

In the present study, we found that the $I-V$ relationship of synaptic currents in stellate cells displayed a wide range of rectification values (from inwardly rectifying to linear) that was correlated with the rate of spontaneous EPSCs. We also obtained direct evidence in these experiments for the idea that activitydependent targeting of GluR2 subunits in the soma reduced $\mathrm{Ca}^{2+}$ permeability of AMPARs in outside-out patches. However, the presence of GluR2-containing receptors did not alter the decay time course of the synaptic current in stellate cells, although other features of the EPSCs were changed.

\section{$\boldsymbol{I} \boldsymbol{V}$ relationship of EPSCs varies between stellate cells}

Does synaptic activity regulate the targeting of GluR2 subunits under physiological conditions? Synaptic activity can modulate AMPAR-mediated transmission by changing the number of
AMPARs at the postsynaptic membrane and by regulating the targeting of the AMPAR subtypes to the synapse (O'Brien et al., 1998; Turrigiano et al., 1998; Carrol et al., 1999; Shi et al., 1999). We have shown previously that EPSCs at the parallel fiber input to the stellate cell synapse exhibit the characteristics expected of GluR2-lacking AMPARs and that expression of GluR2-containing receptors at synapses increases after high-frequency synaptic stimulation (Liu and Cull-Candy, 2000). If this activity-dependent targeting of GluR2-containing AMPARs occurs under normal physiological conditions, one would expect a wide range of rectification values of synaptic currents at different synapses. As predicted, we found that synaptic currents show various degrees of rectification and that the degree of rectification correlated with the rate of spontaneous activity in these cells. This result is consistent with the idea that intrinsic synaptic activity could increase the expression of GluR2-containing AMPARs at these synapses. The rate of spontaneous EPSCs is likely to be related to the low spontaneous activity of presynaptic granule cells (D'Angelo et al., 1995). Furthermore, the frequency of spontaneous synaptic currents in slices may be reduced by the removal of some granule cells during the slicing procedure and therefore could be lower than that in vivo. However, it is also possible that changes in synaptic activity during slice preparation could potentially alter the rectification of EPSCs in cerebellar slices.

The observation that the rectification property of synaptic currents varied from cell to cell is not unique. A wide range of $I-V$ relationships of synaptic current was also found at the mossy-fiber input on stratum lucidum interneurons in the hippocampus (Toth and McBain, 1998).

\section{Activity-dependent change in AMPAR subtypes alters $\mathrm{Ca}^{2+}$ permeability of receptors}

On the basis of the correlation between the rectification properties and $\mathrm{Ca}^{2+}$ permeability, we postulated previously that the activity-dependent change in the rectification properties of EPSCs was accompanied by a decrease in the $\mathrm{Ca}^{2+}$ permeability of receptors. Because it is difficult to directly assess the $\mathrm{Ca}^{2+}$ permeability of synaptic AMPARs by examining the reversal potentials of EPSCs in different external $\mathrm{Ca}^{2+}$ concentrations, we made use of the fact that in stellate cells, neuronal activity also regulates the targeting of somatic AMPAR subtypes.

AMPARs in the soma displayed an outwardly rectifying $I-V$ relationship and therefore would be expected to be $\mathrm{Ca}^{2+}$ imper- 
meable. After suppression of action potential activity with TTX, AMPARs in the soma displayed an inwardly rectifying $I-V$ relationship. We thus determined the $\mathrm{Ca}^{2+}$ permeability of these somatic AMPARs. As predicted, the $\mathrm{Ca}^{2+}$ permeability of AMPARs in outside-out patches from TTX-treated cells was higher than in patches from control cells. The $\mathrm{Ca}^{2+}$ permeability of AMPARs in patches from control stellate cells $\left(\mathrm{P}_{\mathrm{Ca}} /\right.$ $\left.\mathrm{P}_{\mathrm{Na}}=0.25\right)$ appears to be slightly lower than the value described previously in nucleated patches from mouse stellate cells $\left(\mathrm{P}_{\mathrm{Ca}} / \mathrm{P}_{\mathrm{Na}}=0.46\right)$ (Bureau and Mulle, 1998). The $\mathrm{Ca}^{2+}$ permeability of AMPARs from TTX-treated cells was comparable with the values estimated for dentate gyrus basket cells and Hilar interneurons (Geiger et al., 1995). Thus the difference in the rectification properties of AMPAR-mediated currents does indeed correlate with a change in $\mathrm{Ca}^{2+}$ permeability of the receptors in stellate cells, suggesting that the change in EPSC properties after high-frequency synaptic stimulation is likely to result from a change from $\mathrm{Ca}^{2+}$-permeable to $\mathrm{Ca}^{2+}$-impermeable synaptic AMPARs.

\section{Does the presence of the GluR2 subunit affect other properties of EPSCs in stellate cells?}

The decay time constant of synaptic currents in stellate cells is comparable with the deactivation time constant of somatic AMPARs, indicating that receptor deactivation is primarily responsible for the rapid decay of these EPSCs (Barbour et al., 1994). The decay time course of evoked EPSCs in our experiments appeared to be faster than in the previous report (Barbour et al., 1994), possibly because EPSCs were evoked with minimal stimulation to reduce the asynchronous release of transmitter from presynaptic sites.

Synaptic currents that display a rapid time course have also been described at the mossy fiber-cerebellar granule cell synapse (Silver et al., 1996), at the granule cell-basket cell synapse in the hippocampus (Geiger et al., 1997), and at many auditory synapses (Trussell et al., 1993; Barnes-Davies and Forsythe, 1995; Otis et al., 1996; Gardner et al., 1999). Studies of native and recombinant AMPARs have indicated that their desensitization and deactivation kinetics are critically dependent on their subunit composition (Mosbacher et al., 1994; Geiger et al., 1995). Furthermore, it has been proposed that AMPAR-mediated currents display slow gating properties in neurons expressing high levels of GluR $2_{\text {flip }}$ subunits (Geiger et al., 1995).

Synapses in stellate cells contain a mixed AMPAR population that can undergo a rapid activity-dependent switch in subtypes. This allowed us to test whether the expression of the GluR2 subunit affects the kinetics of synaptic currents at this synapse. We have shown previously that high-frequency synaptic activity induces a change from GluR2-lacking to GluR2-containing receptors, with little effect on the decay time course of EPSCs (Liu and Cull-Candy, 2000). In the present study, we found that the decay time constant of the synaptic current mediated by GluR2containing receptors is not significantly different from that mediated by a mixed AMPAR population. Previous studies have shown that a fraction of $\mathrm{Ca}^{2+}$-permeable AMPARs are tonically blocked by polyamines even at negative potentials (Bowie et al., 1998; Rozov and Burnashev, 1999). Could the lack of difference in the decay time course observed in our experiments reflect the fact that a higher-than-expected proportion of GluR2-containing receptors contributed to the evoked EPSCs at hyperpolarized potentials? We have shown that the amplitude of synaptic cur- rents was significantly reduced at depolarized potentials and that synaptic currents mediated by GluR2-lacking AMPARs (measured as the difference between EPSCs at -40 and $+40 \mathrm{mV}$ ) constituted $\sim 77 \%$ of total synaptic currents at $-40 \mathrm{mV}$. Therefore, a substantial amount of the synaptic current at negative potentials was mediated by GluR2-lacking receptors. Together, these results provide evidence that the involvement of GluR2containing AMPARs did not significantly alter the decay time course of the synaptic current in these cells, in contrast to the general expectation that synaptic currents mediated by GluR2containing receptors exhibit slower kinetic properties than GluR2-lacking receptors (Geiger et al., 1995).

This result is consistent with the idea that both $\mathrm{Ca}^{2+}$-permeable and $\mathrm{Ca}^{2+}$-impermeable AMPARs display rapid deactivation kinetics in stellate cells. Several studies on recombinant receptors demonstrate that homomeric GluR1, GluR2, and GluR4 receptors display rapid deactivation kinetics that appear to be similar for flip and flop isoforms (Mosbacher et al., 1994; Koike et al., 2000). Unfortunately, the deactivation time constants of GluR3 homomeric and of GluR2/3 heteromeric receptors, the ones likely to be present at stellate cell synapses (Keinanen et al., 1990; Sato et al., 1993), have not yet been described. Our results imply that the primary effect of inclusion of GluR2 is to modify $\mathrm{Ca}^{2+}$ permeability, with little effect on EPSC time course in stellate cells.

Does inclusion of the GluR2 subunit influence the effect of cyclothiazide on EPSCs? Cyclothiazide preferentially reduces AMPAR desensitization for flip splice variants (Partin et al., 1994, 1995). Furthermore, Partin et al. (1996) demonstrated that cyclothiazide selectively slows the rate of deactivation of GluR $1_{\text {flip }}$ but not deactivation of GluR $1_{\text {flop }}$. The results of our experiments showing that cyclothiazide slowed the decay time course of synaptic currents would suggest the presence of the flip isoform of these subunits in at least a proportion of the synaptic AMPARs.

We also found that cyclothiazide induced a large increase in the amplitude of synaptic currents mediated by a mixed receptor population and little change in the current mediated by GluR2containing receptors. Studies on the potentiation of recombinant AMPARs by cyclothiazide (Yamada and Turetsky, 1996; Cotton and Partin, 2000) show a greater degree of potentiation for GluR $3_{\text {flip }}$ homomeric receptors than for GluR $3_{\text {flip }} / \mathrm{GluR} 2_{\text {flip }}$ heterooligomeric receptors, in agreement with our observation. Another possible explanation would be that the $\mathrm{Ca}^{2+}$-permeable receptors are desensitized more rapidly than GluR2-containing receptors, because GluR $3_{\text {flop }}$ homomeric receptors have faster desensitization kinetics $\left(\tau_{\mathrm{des}}=1.4 \mathrm{msec}\right)$ (Mosbacher et al., 1994).

In conclusion, our experiments demonstrate that synaptic currents in stellate cells display various degrees of rectification. This finding is in agreement with the idea that spontaneous synaptic activity increases the expression of GluR2 subunits at these synapses. Our results raise the possibility that intrinsic synaptic activity, at least in part, controls the targeting of GluR2 subunits at synapses in stellate cells under normal physiological conditions. Expression of GluR2-containing receptors reduces the $\mathrm{Ca}^{2+}$ permeability of AMPARs in outside-out patches but does not significantly alter the kinetics of synaptic currents. Thus, the activity-dependent switch in AMPAR subtypes reduces the $\mathrm{Ca}^{2+}$ entry and sensitivity to block by intracellular spermine. However, inclusion of GluR2-containing receptors produces surprisingly little effect on the EPSC kinetics. 


\section{REFERENCES}

Barbour B, Keller BU, Llano I, Marty A (1994) Prolonged presence of glutamate during excitatory synaptic transmission to cerebellar Purkinje cells. Neuron 12:1331-1343.

Barnes-Davies M, Forsythe I (1995) Pre- and postsynaptic glutamate receptors at a giant excitatory synapse in rat auditory brainstem slices. J Physiol (Lond) 488:387-406.

Bowie D, Mayer M (1995) Inward rectification of both AMPA and kainate subtype glutamate receptors generated by polyamine-mediated ion-channel block. Neuron 15:453-462.

Bowie D, Lange GD, Mayer M (1998) Activity-dependent modulation of glutamate receptors by polyamines. J Neurosci 18:8175-8185.

Bureau I, Mulle C (1998) Potentiation of GABAergic synaptic transmission by AMPA receptors in mouse cerebellar stellate cells: changes during development. J Physiol (Lond) 509:817-831.

Burnashev N, Villarroel A, Sakmann B (1996) Dimensions and ion selectivity of recombinant AMPA and kainate receptor channels and their dependence on Q/R site residues. J Physiol (Lond) 496:165-173.

Carrol RC, Lissin DV, von Zastrow M, Nicoll RA, Malenka RC (1999) Rapid redistribution of glutamate receptors contributes to long-term depression in hippocampal cultures. Nat Neurosci 2:454-460.

Clark BA, Cull-Candy SG (2002) Activity-dependent recruitment of extrasynaptic NMDAR activation by an AMPAR-only synapse. J Neurosci, in press.

Cotton JL, Partin KM (2000) The contributions of GluR2 to allosteric modulation of AMPA receptors. Neuropharmacology 39:21-31.

D’Angelo E, De Filippi G, Rossi P, Taglietti V (1995) Synaptic excitation of individual rat cerebellar granule cells in situ: evidence for the role of NMDA receptors. J Physiol (Lond) 484:397-413.

Dai W-M, Egebjerg J, Lambert JDC (2001) Characteristics of AMPA receptor-mediated responses of cultured cortical and spinal cord neurons and their correlation to the expression of glutamate receptor subunits, GluR1-4. Br J Pharmacol 132:1859-1875.

Diamond JS, Jahr CE (1995) Asynchronous release of synaptic vesicles determined the time course of the AMPA receptor-mediated EPSC. Neuron 15:1097-1107.

Dingledine R, Borges K, Bowie D, Traynelis SF (1999) The glutamate receptor ion channels. Pharmacol Rev 51:7-61.

Gardner SM, Trussell LO, Oertel D (1999) Time course and permeation of synaptic AMPA receptors in cochlear nuclear neurons correlate with input. J Neurosci 19:8721-8729.

Geiger JR, Melcher T, Koh DS, Sakmann B, Seeburg PH, Jonas P, Monyer H (1995) Relative abundance of subunit mRNAs determines gating and $\mathrm{Ca}^{2+}$ permeability of AMPA receptors in principal neurons and interneurons in rat CNS. Neuron 15:193-204.

Geiger JRP, Lubke J, Roth A, Frotscher M, Jonas P (1997) Submillisecond AMPA receptor-mediated signalling at a principal neuroninterneuron synapse. Neuron 18:1009-1023.

Hausser M, Clark BA (1997) Tonic synaptic inhibition modulates neuronal output pattern and spatiotemporal synaptic integration. Neuron 19:665-678.

Hollmann M, Heinemann S (1994) Cloned glutamate receptors. Annu Rev Neurosci 17:31-108.

Ishikawa T, Takahashi T (2001) Mechanisms underlying presynaptic facilitatory effect of cyclothiazide at the calyx of Held of juvenile rats. J Physiol (Lond) 533:423-431.

Jonas P, Burnashev N (1995) Molecular mechanisms controlling calcium entry through AMPA-type glutamate receptor channels. Neuron 15:987-990

Kamboj SK, Swanson GT, Cull-Candy SG (1995) Intracellular spermine confers rectification on rat calcium-permeable AMPA and kainate receptors. J Physiol (Lond) 486:297-303.

Keinanen K, Wisden W, Sommer B, Werner P, Herb A, Verdoorn TA, Sakmann B, Seeberg PH (1990) A family of AMPA-selective glutamate receptors. Science 249:556-560.

Koh D-S, Burnashev N, Jonas P (1995) Block of native $\mathrm{Ca}^{2+}$-permeable AMPA receptors in rat-brain by intracellular polyamines generates double rectification. J Physiol (Lond) 486:305-312.

Koike M, Tsukada S, Tsuzuki K, Kijima H, Ozawa S (2000) Regulation of kinetic properties of GluR2 AMPA receptor channels by alternative splicing. J Neurosci 20:2166-2174.

Lambolez B, Ropert N, Perrais D, Rossier J, Hestrin S (1996) Correlation between kinetics and RNA splicing of alpha-amino-3-hydroxy-5methylisoxazole-4-propionic acid receptors in neocortical neurons. Proc Natl Acad Sci USA 93:1797-1802.

Lewis CA (1979) Ion-concentration dependence of the reversal potential and the single channel conductance of ion channels at the frog neuromuscular junction. J Physiol (Lond) 286:417-445.
Liu SJ, Cull-Candy SG (2000) Synaptic activity at calcium-permeable AMPA receptors induces a switch in receptor subtype. Nature 405:454-458.

Mosbacher J, Schoepfer R, Monyer H, Burnashev N, Seeburg PH, Ruppersberg JP (1994) A molecular determinant for submillisecond desensitization in glutamate receptors. Science 266:1059-1062.

O'Brien RJ, Kamboj S, Ehlers MD, Rosen KR, Fischbach GD, Huganir RL (1998) Activity-dependent modulation of synaptic AMPA receptor accumulation. Neuron 21:1067-1078.

Otis TS, Wu Y-C, Trussell LO (1996) Delayed clearance of transmitter and the role of glutamate transporters at synapses with multiple release sites. J Neurosci 16:1634-1644.

Partin KM, Patneau DK, Mayer ML (1994) Cyclothiazide differentially modulates desensitization of $\alpha$-amino-3-hydroxy-5-methyl-4isoxazolepropionic acid receptor splice variants. Mol Pharmacol 46:129-138.

Partin KM, Bowie D, Mayer ML (1995) Structural determinants of alosteric regulation in alternative spliced AMPA receptors. Neuron 14:833-843.

Partin KM, Fleck MW, Mayer ML (1996) AMPA receptor flip/flop mutants affecting deactivation, desensitization, and modulation by cyclothiazide, aniracetam, and thiocyanate. J Neurosci 16:6634-6647.

Patneau DK, Vyklicky Jr L, Mayer ML (1993) Hippocampal neurons exhibit cyclothiazide-sensitive rapidly desensitizing responses to kainate. J Neurosci 13:3496-3509.

Petralia RS, Wang YX, Mayat E, Wenthold RJ (1997) Glutamate receptor subunit 2-selective antibody shows a differential distribution of calcium-impermeable AMPA receptors among populations of neurons. J Comp Neurol 385:456-476.

Raman IM, Trussell LO (1995) Concentration-jump analysis of voltagedependent conductances activated by glutamate and kainate in neurons of the avian cochlear nucleus. Biophys J 69:1868-1879.

Rozov A, Burnashev N (1999) Polyamine-dependent facilitation of postsynaptic AMPA receptors counteracts paired-pulse depression. Nature 401:594-598

Rubio ME, Wenthold RJ (1997) Glutamate receptors are selectively targeted to postsynaptic sites in neurons. Neuron 18:939-950.

Sato K, Kiyama H, Tohyama M (1993) The differential expression of patterns of messenger RNAs encoding non- $N$-methyl-D-aspartate glutamate receptor subunits (GluR1-4) in the rat brain. Neuroscience $52: 515-539$

Seeburg PH (1993) The molecular biology of mammalian glutamate receptor channels. Trends Pharmacol Sci 14:297-303.

Seeburg PH (1996) The role of RNA editing in controlling glutamate receptor channel properties. J Neurochem 66:1-5.

Shi SH, Hayashi Y, Petralia RS, Zaman SH, Wenthold RJ, Svoboda K, Malinow R (1999) Rapid spine delivery and redistribution of AMPA receptors after synaptic NMDA receptor activation. Science 284:1811-1816.

Silver RA, Colquhoun D, Cull-Candy SG, Edmonds B (1996) Deactivation and desensitization of non-NMDA receptors in patches and the time course of EPSCs in rat cerebellar granule cells. J Physiol (Lond) 493:167-173.

Sommer B, Köhler M, Sprengel R, Seeburg PH (1991) RNA editing in brain controls a determinant of ion flow in glutamate-gated channels. Cell 67:11-19.

Swanson GT, Kamboj SK, Cull-Candy SG (1997) Single-channel properties of recombinant AMPA receptors depend on RNA editing, splice variation, and subunit composition. J Neurosci 17:58-69.

Toth K, McBain CJ (1998) Afferent-specific innervation of two distinct AMPA receptor subtypes on single hippocampal interneurons. Nat Neurosci 1:572-578.

Toth K, McBain CJ (2000) Target-specific expression of pre- and postsynaptic mechanisms. J Physiol (Lond) 525:41-51.

Trussell LO, Zhang S, Raman IM (1993) Desensitization of AMPA receptors upon multiquantal neurotransmitter release. Neuron 10:1185-1196.

Turrigiano GG, Leslie KR, Desai NS, Rutherford LC, Nelson SB (1998) Activity-dependent scaling of quantal amplitude in neocortical neurons. Nature 391:892-896.

Verdoorn TA, Burnashev N, Monyer H, Seeburg PH, Sakmann B (1991) Structural determinants of ion flow through recombinant glutamate receptor channels. Science 252:1715-1718.

Wisden W, Seeburg PH (1993) Mammalian ionotropic glutamate receptors. Curr Opin Neurobiol 3:291-298.

Yamada KA, Turetsky DM (1996) Allosteric interactions between cyclothiazide and AMPA/kainate receptor antagonists. Br J Pharmacol 117:1663-1672. 